Educatio

Vol. 12 No. 1, Juni 2018, hal. 22

\title{
TELAAH WACANA TEKSTUAL PADA BUKU TEKS BAHASA INDONESIA KELAS VII SMP
}

\author{
Faizal Arvianto \\ faizal arvianto@yahoo.com \\ Program Studi Pendidikan Bahasa dan Sastra Indonesia \\ Fakultas Ilmu Pendidikan, Universitas Timor, Indonesia
}

\begin{abstract}
Abstrak
Telaah wacana melihat bahasa dalam teks dan konteks secara bersama-sama dalam suatu komunikasi. Telaah wacana tidak hanya melihat susunan struktur kalimat melainkan juga melihat makna sebagai unsur pentingnya. Oleh karenanya, penafsiran makna tidak hanya dilakukan pada pernyataan dalam teks, tetapi juga dilakukan analisis dari makna yang tersembunyi. Struktur lahir dalam wacana disebut dengan aspek gramatikal, sedangkan struktur batin wacana disebut dengan aspek leksikal. Secara rinci, aspek gramatikal wacana meliputi: pengacuan, penyulihan, pelesapan, dan perangkaian. Aspek leksikal wacana meliputi: pengulangan, sinonim, kolokasi, hiponim, antonim, dan ekuivalensi. Teks yang menjadi bahan telaah adalah teks cerita pendek dan teks narasi yang ada pada "Buku Teks Bahasa Indonesia Kelas VII SMP Kurikulum 2013". Berdasarkan hasil telaah, terdapat dua bagian dari aspek gramatikal yang sangat mendominasi yaitu pengacuan dan konjungsi. Secara leksikal, penelitian ini menemukan beberapa peranti leksikal yaitu repetisi, sinonim, antonim, kolokasi. Peranti yang paling mendominasi kemunculannya adalah repetisi. Terdapat dua jenis repetisi yang dominan, yaitu repetisi epizeuksis dan anafora. Setelah dua jenis repetisi tersebut, repetisi yang sering muncul adalah repetisi nomina. Selain repetisi, kemunculan aspek leksikal yang kedua adalah kolokasi. Antonim dan sinonim menempati peringkat ketiga frekuensi kemunculannya setelah kolokasi. Masing-masing peranti kohesi wacana ini membentuk satu kesatuan wacana yang utuh dan koheren.
\end{abstract}

Kata kunci: telaah, wacana, buku teks

\begin{abstract}
Discourse analysis gives attention to the language in the text and context together in a communication. Discourse analysis does not only look at the structure of sentences but also meaning as an important element. Therefore, the interpretation of meaning is not only done in the statement in the text, but also the analysis of the hidden meaning. The surface structure in discourse is called grammatical aspect, while the internal structure is called the lexical aspect. In detail, the grammatical aspects of discourse include: reference, recovery, percolation, and sequence, while the lexical aspects of discourse include: repetition, synonyms, collocation, hyponym, antonyms, and equivalence. The text that became the subject of the analysis was short stories and narrative text in the "Buku Teks Bahasa Indonesia Kelas VII SMP Kurikulum 2013". Based on the results of the study, there are two parts of the grammatical aspects that are dominant, namely the reference and the conjunction. Lexically, this research found some lexical devices, they are repetition, synonym, antonym and collocation. The dominant device in emergence is repetition. There are two dominant repetitions, namely epizeuksis and anaphora repetition. After those two types of repetitions, the repetition appears frequently is noun repetition. Besides, the emergence of the second lexical aspect is collocation. Antonym and synonyms are in the third rank in the frequency of emergence after collocation. Each of these discourse cohesion devices forms a unified of whole and coherent discourse.
\end{abstract}

Keywords: analysis, discourse, textbook 


\section{PENDAHULUAN}

Kajian ilmu bahasa yang mempelajari wacana disebut dengan analisis atau telaah wacana. Menurut Dardjowidjojo (dalam Mulyana, 2005:1) analisis atau telaah wacana merupakan kajian yang meneliti bahasa, baik dalam bentuk lisan maupun tulis. Kajian wacana berkaitan dengan pemahaman tentang tindakan manusia yang dilakukan dengan bahasa (verbal) dan bukan bahasa (nonverbal). Hal ini menunjukkan bahwa untuk memahami wacana dengan baik dan tepat, diperlukan bekal pengetahuan kebahasaan dan nonkebahasaan (umum).

Menurut Eriyanto (dalam Sobur, 2001:68), analisis/telaah wacana adalah salah satu alternatif atau bagian dari analisis isi. Analisis isi lebih menekankan pada pertanyaan "apa" (what), sedangkan analisis wacana lebih bersifat kualitatif dan lebih melihat pada "bagaimana" (how) dari pesan atau teks komunikasi. Lebih lanjut telaah wacana dapat dikatakan lebih menekankan pada pemaknaan teks. Dasar dari telaah wacana adalah interpretasi, karena telaah wacana merupakan bagian dari metode interpretatif yang mengandalkan interpretasi dan penafsiran peneliti. Melalui telaah wacana kita tidak hanya mengetahui bagaimana isi teks berita, melainkan juga mengetahui bagaimana pesan itu disampaikan. Dengan melihat bagaimana bangunan struktur kebahasaan tersebut, telaah wacana lebih bisa melihat makna yang tersembunyi dari suatu teks.

Ada pandangan lain dalah kajian telaah wacana yang disebut dengan analisis/telaah wacana kritis. Kajian tersebut menekankan bahwa bahasa tidak dipahami sebagai medium netral yang terletak di luar diri pembicara, tetapi dipahami sebagai representasi yang berperan dalam membentuk subjek tertentu, tema-tema wacana tertentu, maupun strategi-strategi di dalamnya. Selain itu, telaah wacana kritis juga mempertimbangkan konteks dari wacana, seperti latar, situasi, peristiwa, dan kondisi (Eriyanto, 2001: 6-8).

Sobur (2001:78) menyatakan bahwa yang penting dalam telaah wacana adalah makna yang ditunjukkan oleh struktur teks. Makna kata dalam telaah wacana adalah praktik yang ingin dikomunikasikan sebagai suatu strategi. Selanjutnya juga dinyatakan bahwa koherensi dalam telaah wacana adalah pertalian atau jalinan antarkata, proposisi, atau kalimat. Dua buah kalimat atau proposisi yang menggambarkan fakta yang berbeda dapat dihubungkan dengan memakai koherensi sehingga fakta yang tidak berhubungan sekalipun dapat menjadi berhubungan ketika komunikator menghubungkannya.

Telaah wacana melihat bahasa dalam teks dan konteks secara bersamasama dalam suatu komunikasi. Bukan hanya susunan struktur kalimat saja yang menjadi perhatian, melainkan makna dari suatu kalimat juga merupakan unsur yang penting dalam telaah wacana. Oleh karena itu, dalam telaah wacana penafsiran makna tidak hanya dilakukan pada pernyataan yang nyata dalam teks, tetapi juga harus dilakukan telaah dari makna yang tersembunyi. 
Andriyani (2013:13) dalam penelitiannya juga menyatakan keutuhan tulisan dapat mencakup kohesi, koherensi dan unsur-unsur gramatikal yang ada di dalam tulisan. Kohesi dan koherensi merupakan bagian yang mutlak yang harus ada dalam suatu tulisan. Kohesi dan koherensi ini akan mencerminkan isi dari tulisan yang akan dibaca oleh pembaca. Kohesi dan koherensi dapat menjadikan tulisan yang dibaca bermakna atau memiliki ide atau informasi yan ingin disampaikan penulis kepada pembaca.

Berdasarkan pemaparan di atas, dapat dikatakan bahwa telaah/analisis wacana merupakan kajian yang meneliti bahasa baik dalam bentuk lisan maupun tulis. Telaah wacana lebih mementingkan makna dengan melihat bahasa dalam teks dan konteks secara bersama-sama dalam suatu komunikasi.

Sejalan dengan pandangan bahwa bahasa terdiri atas bentuk (form) dan makna (meaning), maka hubungan antarbagian wacana dapat dibedakan menjadi dua jenis, yaitu hubungan bentuk yang disebut kohesi (cohesion) dan hubungan makna atau hubungan semantis yang disebut koherensi (coherence). Dengan demikian, wacana yang padu adalah wacana yang apabila dilihat dari segi hubungan bentuk atau struktur lahir bersifat kohesif, dan dilihat dari segi hubungan makna atau struktur batinnya bersifat koheren (Sumarlam, 2003:23).

Istilah koherensi mengandung pengertian pertalian atau hubungan. Dalam konsep kewacanaan koherensi mengacu kepada aspek makna sehingga koherensi dapat berarti pertalian makna (Tarigan, 1993:96). Hubungan koherensi adalah keterkaitan bagian yang satu dengan bagian yang lain, sehingga kalimat memiliki kesatuan makna yang utuh. Selanjutnya, Brown dan Yule (dalam Mulyana, 2005:30) menegaskan bahwa koherensi berarti kepaduan dan keterpahaman antarsatuan dalam suatu teks atau tuturan. Pendapat lain dari Wohl (dalam Tarigan, 1993:104) menyatakan bahwa koherensi adalah pengaturan secara rapi kenyataan dan gagasan, fakta, dan ide menjadi suatu untaian yang logis sehingga mudah memahami pesan yang dikandungnya.

Berdasarkan pernyataan-pernyataan tersebut maka dapat disimpulkan bahwa wacana yang koheren adalah wacana yang mempunyai kebermaknaan suatu teks atau keberterimaan suatu tuturan karena adanya kepaduan semantis. Dengan adanya kepaduan semantis atau pertalian makna antarsatuan dalam suatu wacana akan lebih mudah memahami pesan yang dikandungnya. Koherensi sebuah wacana juga diartikan sebagai hubungan antara teks dan faktor di luar teks berdasarkan konteks.

Kohesi merupakan salah satu unsur yang turut menentukan keutuhan wacana. Dalam kata kohesi tersirat pengertian kepaduan, keutuhan. Hal itu bila dikaitkan dengan aspek bentuk dan makna, maka dapat dikatakan bahwa kohesi mengacu kepada aspek bentuk yang selanjutnya mengacu kepada aspek formal bahasa. Kohesi sebagai aspek formal bahasa dalam wacana diartikan sebagai kepaduan bentuk yang secara struktural membentuk ikatan sintaktikal atau 
merupakan wadah kalimat-kalimat yang disusun secara padu dan padat untuk menghasilkan tuturan (Tarigan, 1993:96). Konsep kohesi pada dasarnya mengacu kepada hubungan bentuk. Artinya, unsur-unsur wacana (kata atau kalimat) yang digunakan untuk menyusun suatu wacana memiliki keterkaitan secara padu dan utuh. Dengan kata lain, kohesi termasuk dalam aspek internal struktur wacana (Mulyana, 2005:26).

Berkenaan dengan masalah kohesi, Halliday dan Hasan (1976:5) membagi kohesi menjadi dua jenis, yaitu kohesi gramatikal dan kohesi leksikal. Dalam telaah wacana, segi bentuk atau struktur lahir wacana disebut dengan aspek gramatikal wacana. Bentuk lainnya yaitu dari segi makna atau struktur batin wacana disebut dengan aspek leksikal wacana. Secara lebih rinci, aspek gramatikal wacana meliputi: pengacuan (reference), penyulihan (substitution), pelesapan (ellipsis), dan perangkaian (conjunction). Kohesi leksikal wacana dibedakan menjadi enam macam pengulangan (repetisi), sinonim (padan kata), kolokasi (sanding kata), hiponim (hubungan atas-bawah), antonim (lawan kata), dan ekuivalensi (kesepadanan).

Selanjutnya Halliday dan Hasan (1976:5) juga menyatakan bahwa kohesi merupakan satu set kemungkinan yang terdapat dalam bahasa untuk menjadikan suatu "teks" itu memiliki kesatuan. Hal ini berarti bahwa hubungan makna, baik makna leksikal maupun gramatikal perlu diwujudkan secara terpadu dalam kesatuan yang membentuk teks.

Cohesion is expressed through the stratal organization of language. Language can be explained as a multiple coding system comprising three levels of coding or "strata". The semant ic (meaning), the lexigramatical (forms) and the phonological and orthographic (expression). Meaning are realized (coded) as forms, and the forms are realized in turn (recoded) as expression. To put this in everyday terminology, meaning is put into wording and wording into sound or writing."

Halliday dan Hasan (1976:5) telah mencoba melihat kohesi makna itu dari dua sudut, yaitu kohesi leksikal dan kohesi gramatikal yang terdapat dalam suatu kesatuan teks. Kohesi ini juga memperlihatkan jalinan ujaran dalam bentuk kalimat untuk membentuk suatu teks atau konteks dengan cara menghubungkan makna yang terkandung di dalam unsur. Senada dengan pendapat tersebut, Djajasudarma memberikan pengertian mengenai kohesi yaitu keserasian hubungan antara unsur yang satu dengan unsur yang lain dalam wacana sehingga terciptalah pengertian yang apik atau koheren (1994:46). Dari pengetian ini jelas bahwa wacana itu akan koheren apabila terjalin keserasian di antara unsur-unsurnya. 
Sebagaimana telah disebutkan sebelumnya, bahwa Halliday dan Hasan membagi kohesi menjadi dua jenis, yaitu kohesi gramatikal dan kohesi leksikal. Aspek gramatikal wacana meliputi: pengacuan (reference), penyulihan (substitution), pelesapan (ellipsis), dan perangkaian (conjunction).

\section{1) Pengacuan (Referensi)}

Pengacuan atau referensi adalah salah satu jenis kohesi gramatikal yang berupa satuan lingual tertentu yang mengacu pada satuan lingual lain (atau suatu acuan) yang mendahului atau mengikutinya. Berdasarkan tempatnya, pengacuan dapat dibedakan menjadi dua, yaitu pengacuan endofora apabila acuannya (satuan lingual yang diacu) berada atau terdapat di dalam teks wacana itu, dan pengacuan eksofora apabila acuannya berada atau terdapat di luar teks wacana.

Berdasarkan arah pengacuan endofora dibedakan menjadi dua jenis, yaitu (1) pengacuan anaforis (anaphoric reference) adalah salah satu kohesi gramatikal yang berupa satuan lingual tertentu yang mengacu pada satuan lingual lain yang mendahuluinya, atau mengacu anteseden di sebelah kiri. (2) pengacuan kataforis (cataphoric reference) adalah salah satu kohesi gramatikal yang berupa satuan lingual tertentu yang mengacu pada satuan lingual lain yang mengikutinya, atau mengacu anteseden di sebelah kanan. Jenis kohesi gramatikal pengacuan tersebut diklasifikasikan menjadi tiga macam, yaitu (1) pengacuan persona, (2) pengacuan demonstratif, dan (3) pengacuan komparatif. (Sumarlam, 2003:23-24).

\section{2) Penyulihan (Substitusi)}

Penyulihan (substitusi) ialah salah satu jenis kohesi gramatikal yang berupa penggantian satuan lingual tertentu (yang telah disebut) dengan satuan lingual lain dalam wacana untuk memperoleh unsur pembeda. Dilihat dari satuan lingualnya substitusi dapat dibedakan menjadi substitusi nominal, verbal, frasal, dan klausal.

\section{3) Pelesapan (Elipsis)}

Pelesapan (elipsis), ialah salah satu jenis kohesi gramatikal yang berupa penghilangan atau pelesapan satuan lingual tertentu yang telah disebutkan sebelumnya (Sumarlam, 2003:30).

\section{4) Perangkaian (Konjungsi)}

Konjungsi adalah salah satu jenis kohesi gramatikal yang dilakukan dengan cara menghubungkan unsur yang satu dengan unsur yang lain dalam wacana (Sumarlam, 2003:32). Ada beberapa jenis konjungsi dan maknanya sebagai perangkaian unsur dalam wacana, misalnya konjungsi sebab-akibat (kausalitas) yang meliputi: sebab, karena, maka, makanya; konjungsi penambahan (aditif) meliputi: dan, juga, serta; konjungsi urutan (sekuensial) meliputi: lalu, terus, kemudian; dan sebagainya. 
Kepaduan wacana selain didukung oleh aspek gramatikal atau kohesi gramatikal juga didukung oleh aspek leksikal atau kohesi leksikal. Kohesi leksikal adalah hubungan antarunsur dalam wacana secara semantis. Dalam hal ini, untuk menghasilkan wacana yang padu pembicara atau penulis dapat menempuhnya dengan cara memilih kata-kata yang sesuai dengan isi kewacanaan yang dimaksud. Hubungan kohesif yang diciptakan atas dasar aspek leksikal, dengan pilihan kata yang serasi, menyatakan hubungan makna atau relasi semantik antara satuan lingual yang satu dengan satuan lingual yang lain dalam wacana (Sumarlam, 2003:35).

Kohesi leksikal dalam wacana dapat dibedakan menjadi enam macam, yaitu repetisi (pengulangan), sinonim (padan kata), kolokasi (sanding kata), hiponim (hubungan atas-bawah), antonim (lawan kata), dan ekuivalensi (kesepadanan).

\section{1) Pengulangan (Repetisi)}

Repetesi adalah pengulangan satuan lingual (bunyi, suku kata, kata, atau bagian kalimat) yang dianggap penting untuk memberi tekanan dalam sebuah konteks yang sesuai. Berdasarkan tempat satuan lingual yang diulang dalam baris, klausa atau kalimat, repetisi dibedakan menjadi delapan macam, yaitu epizeuksis, tautotes, anafora, epistrofa, simploke, mesodiplosis, epanalepsis, dan anadiplosis.

\section{2) Padan kata (Sinonim)}

Padan kata (sinonim) dapat diartikan sebagai nama lain untuk benda atau hal yang sama, atau ungkapan yang maknanya kurang lebih sama dengan ungkapan lain. Sinonim merupakan salah satu aspek leksikal untuk mendukung kepaduan wacana (Sumarlam, 2003:39). Selanjutnya Wijana \& Rohmadi (2008:28) menyatakan bahwa sinonim adalah hubungan atau relasi persamaan makna. Jadi, bentuk kebahasaan yang satu memiliki kesamaan makna dengan bentuk kebahasaan lain.

\section{3) Sanding Kata (Kolokasi)}

Sanding Kata atau Kolokasi adalah asosiasi tertentu dalam menggunakan pilihan kata yang cenderung digunakan secara berdampingan.

\section{4) Lawan Kata (Antonim)}

Antonim berasal dari anti atau "ant" yang berarti lawan dan "onuma" yang berarti nama. Antonim kemudian diartikan sebagai kata-kata yang berbeda atau berlawanan maknanya (Kosasih, 2011:155). Lawan kata atau antonim dapat diartikan juga sebagai nama lain untuk benda/hal yang lain, ataupun sebuah satuan lingual yang maknanya berlawanan/beroposisi dengan satuan lingual yang lain.

\section{5) Hubungan Atas-Bawah (Hiponim)}

Hubungan atas-bawah atau hiponim dapat diartikan sebagai satuan bahasa (kata, frasa, kalimat) yang maknanya dianggap merupakan 
bagian dari makna satuan lingual yang lain. Unsur atau satuan lingual yang mencakupi beberapa unsur atau satuan lingual yang berhiponim itu disebut hipernim atau superordinat.

\section{6) Kesepadanan (Ekuivalensi)}

Kesepadanan atau ekuivalensi adalah hubungan kesepadanan antara satuan lingual yang lain dalam sebuah paradigma. Dalam hal ini, sejumlah kata hasil proses afiksasi dari morfem asal yang sama menunjukkan adanya hubungan kesepadanan.

\section{HASIL DAN PEMBAHASAN}

Bagian inti dari kajian ini adalah telaah data. Dalam hal ini satuan unit telaah adalah teks. Teks tersebut merupakan bentuk tertulis yang berupa cerita pendek dan narasi yang ada pada Buku Teks Bahasa Indonesia Kelas VII SMP Kurikulum 2013.

\section{Cerita Pendek "Bawang Merah dan Bawang Putih" \\ a. Telaah Aspek Gramatikal}

Peranti wacana yang biasa digunakan untuk mendukung kepaduan wacana dari segi aspek gramatikal meliputi pengacuan (reference), penyulihan (substitution), pelesapan (ellipsis), dan perangkaian (conjunction).

\section{1) Pengacuan (Referensi)}

Pengacuan (referensi) merupakan salah satu jenis kohesi gramatikal berupa satuan lingual tertentu yang mengacu pada satuan lingual lain (atau suatu referen) yang mendahului atau mengikutinya. Dalam cerita pendek "Bawang Merah dan Bawang Putih" terdapat dua macam pengacuan, yaitu pengacuan persona dan pengacuan demonstratif. Masing-masing pengacuan dibahas sebagai berikut.

\section{a) Pengacuan Persona}

Pengacuan persona yang terdapat dalam cerita pendek "Bawang Merah dan Bawang Putih" adalah pengacuan persona ketiga tunggal bentuk bebas (ia, dia, -nya dan beliau) dan terikat (mereka).

(1) Bawang putih sangat berduka, demikianlah juga ayahnya. Sekarang Bawang Putih hanya tinggal berdua bersama ayahnya.

(2) Dia kerap membawakan makananan, menolong Bawang Putih membereskan tempat tinggal atau cuma menemani Bawang Putih serta ayahnya mengobrol.

(3) Dia mendapatkan ibu baru sekaligus saudara perempuan, yaitu bawang Merah.

(4) Mereka sering memarahi bawang putih serta memberinya pekerjaan berat bila ayah mereka pergi berdagang.

(5) Sudah pasti sang ayah tidak mengetahuinya karena bawang putih tidak pernah mengadukan tingkah ibu dan saudara tirinya itu. 
(6) Tinggallah bawang putih bersama ibu dan saudara tirinya.

(7) Hari demi hari bawang putih disiksa oleh bawang merah dan ibunya.

(8) Suatu hari, bawang putih mencuci baju ibu dan saudara tirinya di sungai

(9) Dia mau menyerahkan baju itu jika bawang putih mau membantunya membersihkan rumah.

(10) Nenek itu terkesan dengan ketekunan bawang putih melakukan tugasnya membersihkan rumah.

(11) Sesampai di rumah, dia ceritakan pengalamannya dan dibukanya bungkusan yang diberikan nenek.

(12) Keesokan harinya, karena rasa iri hati yang sangat bawang merah melakukan hal yang sama dengan peristiwa yang dialami bawang putih.

(13) Dia menghanyutkan bajunya di sungai, dan mengikutinya sampai ia berada di depan rumah nenek.

(14) Nenek pun menjawab bahwa baju itu dia simpan.

(15) Sang nenek memberikan baju dan sebuah bungkusan yang bentuknya sama dengan bungkusan yang diberikan kepada bawang putih.

(16) Setelah sampai di rumah, bawang merah berteriak memanggil ibunya.

\section{b) Pengacuan Demonstratif}

Pengacuan demonstratif meliputi pengacuan demonstratif waktu (temporal) dan pengacuan demonstratif tempat (lokasional).

- Pengacuan demonstratif waktu di dalam cerita pendek ini ditunjukkan pada kalimat berikut:

(1) Pada zaman dahulu, di sebuah desa tinggal sebuah keluarga yang bahagia.

(2) Keluarga itu mempunyai anak yang cantik bernama Bawang Putih. Kehidupan bahagia itu terganggu saat ibu Bawang Putih sakit keras dan pada akhirnya meninggal.

(3) Bawang putih sangat berduka, demikianlah juga ayahnya. Sekarang Bawang Putih hanya tinggal berdua bersama ayahnya.

(4) Sejak ibu Bawang Putih meninggal, ibu Bawang Merah kerap berkunjung ke tempat tinggal Bawang Putih.

(5) Akhirnya, sang janda itu menikah dengan ayah bawang putih.

(6) Pada awalnya, sang ibu tiri dan saudara tiri itu amat baik pada bawang putih, tetapi lama kelamaan karakter asli mereka mulai terlihat. 
(7) Suatu hari, ayah bawang putih sakit keras dan kemudian meninggal.

(8) Hari demi hari bawang putih disiksa oleh bawang merah dan ibunya.

(9) Suatu hari, bawang putih mencuci baju ibu dan saudara tirinya di sungai.

(10) Setelah selesai, bawang putih berpamit pada sang nenek.

(11) Keesokan harinya, karena rasa iri hati yang sangat bawang merah melakukan hal yang sama dengan peristiwa yang dialami bawang putih.

- Pengacuan demonstratif tempat dalam cerita pendek ini terdapat pada kalimat berikut.

(1) Di desa itu, hiduplah seorang janda yang mempunyai anak bernama Bawang Merah.

(2) Sejak ibu Bawang Putih meninggal, ibu Bawang Merah kerap berkunjung ke tempat tinggal Bawang Putih.

(3) Dia kerap membawakan makananan, menolong Bawang Putih membereskan tempat tinggal atau cuma menemani Bawang Putih serta ayahnya mengobrol.

(4) Suatu hari, bawang putih mencuci baju ibu dan saudara tirinya di sungai.

(5) Sampailah dia di sebuah rumah, yang dihuni seorang nenek yang berada di tepi sungai.

(6) Bungkusan itu tidak boleh dibuka jika belum sampai di rumah.

(7) Sesampai di rumah, dia ceritakan pengalamannya dan dibukanya bungkusan yang diberikan nenek.

(8) Ternyata di dalam bungkusan itu terdapat emas yang berkilauan banyak sekali.

(9) Dia menghanyutkan bajunya di sungai, dan mengikutinya sampai ia berada di depan rumah nenek.

(10) Bawang merah bertanya apakah nenek melihat baju hanyut di sungai?

(11) Dengan berlari riang, bawang merah kembali ke rumah dan ingin segera membuka bungkusan dari nenek.

(12) Setelah sampai di rumah, bawang merah berteriak memanggil ibunya.

(13) Namun, di dalam bungkusan itu bukan emas berkilau, tetapi ular yang mengejar ibu tiri dan bawang merah yang berlari pergi dari rumah bawang putih, pergi dari desa tempat bawang putih tinggal. 


\section{c) Pelesapan (Elipsis)}

Pelesapan atau Elipsis pada cerita pendek akan dipaparkan di bawah ini.

(1) Keluarga itu mempunyai anak yang cantik bernama Bawang Putih. Kehidupan bahagia ----------- itu terganggu saat ibu Bawang Putih sakit keras dan pada akhirnya meninggal.

\section{d) Perangkaian (Konjungsi)}

Konjungsi yang terdapat dalam cerita pendek sebagi berikut.

(1) Keluarga itu mempunyai anak yang cantik bernama Bawang Putih. Kehidupan bahagia ----------- itu terganggu saat ibu Bawang Putih sakit keras dan pada akhirnya meninggal.

(2) Bawang putih sangat berduka, demikianlah juga ayahnya.

(3) Dia kerap membawakan makananan, menolong Bawang Putih membereskan tempat tinggal atau cuma menemani Bawang Putih serta ayahnya mengobrol.

(4) Pada awalnya, sang ibu tiri dan saudara tiri itu amat baik pada bawang putih, tetapi lama kelamaan karakter asli mereka mulai terlihat.

(5) Mereka sering memarahi bawang putih serta memberinya pekerjaan berat bila ayah mereka pergi berdagang.

(6) Sudah pasti sang ayah tidak mengetahuinya karena bawang putih tidak pernah mengadukan tingkah ibu dan saudara tirinya itu.

(7) Namun, bawang putih menerima kehidupan itu dengan tabah.

(8) Suatu hari, bawang putih mencuci baju ibu dan saudara tirinya di sungai.

(9) Dia mau menyerahkan baju itu jika bawang putih mau membantunya membersihkan rumah.

(10) Nenek itu juga memberi bungkusan hadiah untuk bawang putih karena telah bekerja membersihkan rumah nenek.

(11) Bungkusan itu tidak boleh dibuka jika belum sampai di rumah.

(12) Sesampai di rumah, dia ceritakan pengalamannya dan dibukanya bungkusan yang diberikan nenek.

(13) Keesokan harinya, karena rasa iri hati yang sangat bawang merah melakukan hal yang sama dengan peristiwa yang dialami bawang putih.

(14) Dia menghanyutkan bajunya di sungai, dan mengikutinya sampai ia berada di depan rumah nenek.

(15) Nenek pun menjawab bahwa baju itu dia simpan.

(16) Bawang merah menolak membersihkan rumah dan tetap meminta baju itu. 
(17) Sang nenek memberikan baju dan sebuah bungkusan yang bentuknya sama dengan bungkusan yang diberikan kepada bawang putih.

(18) Dengan berlari riang, bawang merah kembali ke rumah dan ingin segera membuka bungkusan dari nenek.

(19) Ibu dan anak itu segera membuka bungkusan.

(20) Namun, di dalam bungkusan itu bukan emas berkilau, tetapi ular yang mengejar ibu tiri dan bawang merah yang berlari pergi dari rumah bawang putih pergi dari desa tempat bawang putih tinggal.

\section{b. Telaah Aspek Leksikal}

Kepaduan wacana teks cerita pendek selain didukung oleh aspek gramatikal atau kohesi gramatikal juga didukung oleh aspek leksikal atau kohesi leksikal. Kohesi leksikal dalam wacana dapat dibedakan menjadi enam macam, yaitu repetisi (pengulangan), sinonim (padan kata), kolokasi (sanding kata), hiponim (hubungan atas-bawah), antonim (lawan kata/oposisi makna), dan ekuivalensi (kesepadanan bentuk). Dari keenam peranti kohesi leksikal itu, tentu tidak semuanya dimanfaatkan oleh penulis cerpen. Dalam teks cerpen "Bawang Merah dan Bawang Putih" peranti kohesi leksikal diperlukan untuk menghasilkan teks cerpen sebagai sebuah wacana yang padu. Berikut hasil telaah teks dari aspek leksikal.

\section{1) Repetisi}

Repetisi adalah pengulangan satuan lingual (bunyi, suku kata, kata, atau bagian kalimat) yang dianggap penting untuk memberikan tekanan dalam sebuah konteks yang sesuai. Dalam teks cerpen "Bawang Merah dan Bawang Putih" terdapat beberapa jenis repetisi (pengulangan) yang menonjol, yaitu.

\section{a) Repetisi epizeuksis}

(1) Pada zaman dahulu, di sebuah desa tinggal sebuah keluarga yang bahagia. Keluarga itu mempunyai anak yang cantik yang bernama Bawang Putih.

(2) Sejak ibu Bawang Putih meninggal, ibu Bawang Merah kerap berkunjung ke tempat tinggal Bawang Putih. Dia kerap membawakan makanan, menolong Bawang Putih membereskan tempat tinggal atau cuma menemani Bawang Putih serta ayahnya mengobrol.

(3) Keesokan harinya, karena rasa iri hati yang sangat bawang merah melakukan hal yang sama dengan peristiwa yang dialami bawang putih.

(4) Bawang merah bertanya apakah nenek melihat baju hanyut di sungai? 
(5) Baju itu akan diberikan kepada bawang merah asal bawang merah mau membantu membersihkan rumah.

(6) Bawang merah menolak membersihkan rumah dan tetap meminta baju itu.

(7) Dengan berlari riang, bawang merah kembali ke rumah dan ingin segera membuka bungkusan dari nenek.

(8) Setelah sampai di rumah, bawang merah berteriak memanggil ibunya.

(9) Namun, di dalam bungkusan itu bukan emas berkilau, tetapi ular yang mengejar ibu tiri dan bawang merah yang berlari pergi dari rumah bawang putih, pergi dari desa tempat bawang putih tinggal.

Data (1) dan (2) menunjukkan adanya repetisi epizeuksis. Hal ini bisa dilihat dari pengulangan salah satu unsur dari wacana tersebut yang terjadi secara berturut-turut. Unsur yang diulang pada data (1) berupa nomina keluarga yang diulang sebanyak dua kali. Data (2) berupa nomina Bawang Putih yang diulang sebanyak empat kali, sedangkan data (3) sampai (9) berupa nomina Bawang Merah yang diulang sebanyak tujuh kali.

\section{b) Repetisi Anafora}

Repetisi anafora ialah pengulangan satuan lingual berupa kata atau frasa pertama pada tiap baris atau kalimat berikutnya.

(1) Suatu hari, Bawang Putih mencuci baju ibu dan saudaranya di sungai. Ada satu baju yang terhanyut, Bawang Putih pun mengejar baju itu.

(2) Sampailah dia di sebuah rumah yang dihuni seorang nenek yang berada di tepi sungai. Nenek itu menyimpan baju Bawang Putih yang hanyut.

(3) Nenek itu menyimpan baju Bawang Putih yang hanyut. Dia mau menyerahkan baju itu jika Bawang Putih mau membantunya membersihkan rumah. Bawang Putih pun segera membantu nenek membersihkan rumah. Nenek itu terkesan dengan ketekunan Bawang Putih melakukan tugasnya membersihkan rumah. Nenek itu juga memberi bungkusan hadiah untuk Bawang Putih karena telah bekerja membersihkan rumah nenek.

(4) Nenek itu juga memberi bungkusan hadiah untuk Bawang Putih karena telah bekerja membersihkan rumah nenek. Bungkusan itu tidak boleh dibuka jika belum sampai rumah.[...] Sesampai di rumah dia menceritakan pengalamannya dan dibukanya bungkusan yang diberikan nenek. Ternyata di dalam bungkusan itu terdapat emas yang berkilauan banyak sekali. 


\section{2) Antonim (Lawanan Kata) Oposisi Majemuk}

(1) Bawang merah bertanya apakah nenek melihat baju hanyut di sungai? Nenek pun menjawab bahwa baju itu dia simpan.

\section{3) Kolokasi (Sanding Kata)}

Kolokasi atau sanding kata adalah asosiasi tertentu dalam menggunakan pilihan kata yang cenderung digunakan secara berdampingan. Kata-kata yang berkolokasi adalah kata-kata yang cenderung dipakai dalam suatu ranah tertentu untuk mendukung suatu tema tertentu. Mengingat cerpen "Bawang Merah dan Bawang Putih" bertema kekejaman ibu tiri, maka kata-kata yang dipilih dan dipakai secara berdampingan untuk mendukung tema itu pun juga kata-kata yang bermakna sejalan dengan tema ceritanya. Kata-kata yang saling berkolokasi dan mendukung kepaduan kepaduan wacana teks cerpen tersebut adalah kata berduka, disiksa, tabah. Beberapa baris kalimat yang didalamnya terdapat kata-kata yang berkolokasi itu tampak pada kutipan berikut.

(1) Bawang Putih sangat berduka, demikianlah juga ayahnya.

(2) Hari demi hari Bawang Putih disiksa oleh Bawang Merah.

(3) Namun Bawang Putih menerima kehidupan ini dengan tabah.

\section{Telaah Teks Biografi yang Berjudul "Ki Hajar Dewantara Bapak Pendidikan Indonesia"}

Telaah tekstual biografi "Ki Hajar Dewantara Bapak Pendidikan Indonesia" ini meliputi telaah gramatikal dan telaah leksikal.

\section{a. Telaah Aspek Gramatikal}

Peranti wacana yang biasa digunakan untuk mendukung kepaduan wacana dari segi aspek gramatikal meliputi pengacuan (reference), penyulihan (substitution), pelesapan (ellipsis), dan perangkaian (conjunction).

\section{1) Pengacuan (Referensi)}

Pengacuan (referensi) merupakan salah satu jenis kohesi gramatikal berupa satuan lingual tertentu yang mengacu pada satuan lingual lain (atau suatu referen) yang mendahului atau mengikutinya. Dalam biografi "Ki Hajar Dewantara Bapak Pendidikan Indonesia" terdapat tiga macam pengacuan, yaitu pengacuan persona, pengacuan demonstratif, dan pengacuan komparatif. Masing-masing pengacuan dibahas sebagai berikut.

\section{a) Pengacuan Persona}

Pengacuan persona yang terdapat dalam biografi "Ki Hajar Dewantara Bapak Pendidikan Indonesia" adalah pengacuan persona ketiga tunggal bentuk bebas dan terikat. 
Pengacuan persona ketiga tunggal ditandai dengan kata ia dan -nya yang terdapat pada kalimat di bawah ini:

(1) Ia lahir di Yogyakarta pada tanggal 2 Mei 1889.

(2) Ia berasal dari lingkungan keluarga Keraton Yogyakarta.

(3) Meskipun demikian, ia sangat sederhana dan ingin dekat dengan rakyatnya.

(4) Tujuannya berganti nama adalah agar ia dapat bebas dekat dengan rakyatnya.

(5) Ki Hajar Dewantara menamatkan Sekolah Dasar di ELS (Sekolah Dasar Belanda), kemudian melanjutkan pendidikannya ke STOVIA (Sekolah Dokter Bumiputera).

(6) Ia tidak dapat menamatkan pendidikan di sekolah tersebut karena sakit.

(7) Setelah itu, ia bekerja sebagai wartawan di beberapa surat kabar, seperti Sedyotomo, Midden Java, De Express, Oetoesan Hindia, Kaoem Moeda, Tjahaja Timoer, dan Poesara.

(8) Tulisan-tulisannya sangat komunikatif, tajam, dan patriotik sehingga mampu membangkitkan semangat antikolonial bagi pembacanya.

(9) Pada tahun 1908, ia aktif di seksi propaganda Boedi Oetomo untuk menyosialosasikan dan menggugah kesadaran masyarakat Indonesia.

(10) Ia selalu menyampaikan tentang pentingnya persatuan dan kesatuan dalam berbangsa dan bernegara.

(11) Pada tanggal 25 Desember 1912, ia mendirikan Indische Partij (partai politik pertama yang beraliran nasionalisme Indonesia) bersama Douwes Dekker (Dr. Danudirdja Setyabudhi) dan dr. Cipto Mangoenkoesoemo.

(12) Pada bulan November 1913 ia membentuk Komite Bumipoetra.

(13) Komite Bumipoetra melancarkan kritik terhadap Pemerintah Belanda yang ingin merayakan seratus tahun kebebasan Belanda dari penjajahan Prancis dengan menarik uang dari rakyat jajahannya.

(14) Ki Hajar Dewantara juga mengecam rencana perayaan itu melalui tulisannya yang berjudul "Als Ik Eens Nederlander was (Seandainya Aku Seorang Belanda) dan Een voor Allen maar Ook Allen voor Een (Satu untuk Semua, tetapi Semua untuk Satu juga)".

(15) Akibat karangannya itu, pemerintah kolonial Belanda melalui Gubernur Jendral Idenburg menjatuhkan hukum buang (internering) ke Pulau Bangka tanpa proses pengadilan. 
(16) Kemudian, ia dibuang ke Negara Belanda bersama kedua rekannya dan kembali ke tanah air pada tahun 1918 setelah memperoleh Europeesche Akte.

(17) Pada tanggal 3 Juli 1922 Ki Hajar Dewantara bersama dengan rekan-rekan seperjuangannya mendirikan perguruan yang bercorak nasional,

(18) Melalui perguruan Taman Siswa dan tulisan-tulisannya yang berjumlah ratusan,

(19) Ki Hajar Dewantara tidak hanya dianggap sebagai tokoh dan pahlawan pendidikan yang tanggal kelahirannya 2 Mei dijadikan hari Pendidikan Nasional,

(20) Sebagai pahlawan yang dijuluki Bapak Pendidikan Indonesia, semangat dan jasa Ki Hajar Dewantara sepantasnya dikenang dan tidak dilupakan.

(21) Semoga apa yang dilakukannya itu dapat menginspirasi rakyat Indonesia menuju masa depan yang lebih baik.

\section{b) Pengacuan Demonstratif}

Pengacuan demonstratif meliputi pengacuan demonstratif waktu (temporal) dan pengacuan demonstratif tempat (lokasional).

- Pengacuan demonstratif waktu di dalam biografi ini ditunjukkan pada kalimat berikut:

(1) Ia lahir di Yogyakarta pada tanggal 2 Mei 1889.

(2) Ketika berusia 40 tahun menurut hitungan Tahun Caka, Raden Mas Soewardi Soeryaningrat berganti nama menjadi Ki Hajar Dewantara.

(3) Pada tahun 1908, ia aktif di seksi propaganda Boedi Oetomo untuk menyosialosasikan dan menggugah kesadaran masyarakat Indonesia.

(4) Pada tanggal 25 Desember 1912, ia mendirikan Indische Partij (partai politik pertama yang beraliran nasionalisme Indonesia) bersama Douwes Dekker (Dr. Danudirdja Setyabudhi) dan dr. Cipto Mangoenkoesoemo.

(5) Pada bulan November 1913 ia membentuk Komite Bumipoetra.

(6) Kemudian, ia dibuang ke Negara Belanda bersama kedua rekannya dan kembali ke tanah air pada tahun 1918 setelah memperoleh Europeesche Akte.

(7) Pada tanggal 3 Juli 1922 Ki Hajar Dewantara bersama dengan rekan-rekan seperjuangannya mendirikan perguruan yang bercorak nasional, 
(8) Ki Hajar Dewantara tidak hanya dianggap sebagai tokoh dan pahlawan pendidikan yang tanggal kelahirannya 2 Mei dijadikan hari Pendidikan Nasional,

(9) Ki Hajar Dewantara meninggal dunia pada tanggal 28 April 1959 di Yogyakarta.

- Pengacuan demonstratif tempat dalam biografi ini terdapat pada kalimat berikut:

(1) Ia lahir di Yogyakarta pada tanggal 2 Mei 1889.

(2) Ki Hajar Dewantara meninggal dunia pada tanggal 28 April 1959 di Yogyakarta.

(3) Untuk melestarikan nilai dan semangat perjuangan Ki Hajar Dewantara penerus Taman Siswa mendirikan museum Dewantara Kirti Griya di Yogyakarta.

\section{c) Pengacuan Komparatif}

Pengacuan komparatif adalah salah satu jenis kohesi gramatikal yang bersifat membandingkan dua hal atau lebih yang memiliki kesamaan dalam bentuk sikap, sifat, watak, perilaku, dan sebagainya. Kata-kata yang digunakan untuk membandingkan, yaitu seperti, bagai, bagaikan, laksana, sama dengan, tidak berbeda dengan, persis seperti, dan persis sama dengan. Adapun pengacuan komparatif yang terdapat dalam biografi adalah:

(1) Setelah itu, ia bekerja sebagai wartawan di beberapa surat kabar, seperti Sedyotomo, Midden Java, De Express, Oetoesan Hindia, Kaoem Moeda, Tjahaja Timoer, dan Poesara.

\section{2) Penyulihan (Substitusi)}

Penyulihan atau substitusi adalah salah satu jenis kohesi gramatikal yang berupa penggantian satuan lingual tertentu (yang telah disebut) dengan satuan lingual lain dalam wacana untuk memperoleh unsur pembeda (Sumarlam, dkk. 2003: 28). Substitusi dapat dibedakan menjadi empat, yaitu: (a) substitusi nomina, (b) substitusi verbal, (c) substitusi frasal, dan (d) substitusi klausal. Substitusi yang terdapat dalam biografi ini adalah substitusi nominal. Hal ini ditunjukkan pada kalimat sebagai berikut.

(1) Perjalanan hidup Ki Hajar Dewantara benar-benar ditandai dengan perjuangan dan pengabdian pada kepentingan bangsa dan negara.

(2) Akan tetapi, organisasi ini ditolak oleh pemerintahan Belanda karena dianggap dapat membangkitkan rasa nasionalisme rakyat dan menggerakkan kesatuan untuk menentang pemerintah kolonial Belanda.

\section{3) Pelesapan (Elipsis)}


Menurut Sumarlam, dkk (2003: 30) pelesapan (elipsis) adalah salah satu jenis kohesi gramatikal yang berupa penghilangan atau pelesapan satuan lingual tertentu yang telah disebutkan sebelumnya. Dalam hal ini yang dilesapkan dapat berupa kata, frasa, klausa, kalimat. Adapun pelesapan yang terdapat dalam biografi ini adalah:

(1) Kemudian, ia dibuang ke Negara Belanda bersama kedua rekannya dan kembali ke tanah air pada tahun 1918 setelah memperoleh Europeesche Akte.

\section{4) Perangkaian (Konjungsi)}

Konjungsi yang terdapat dalam biografi ini adalah:

(1) Meskipun demikian, ia sangat sederhana dan ingin dekat dengan rakyatnya.

(2) Tujuannya berganti nama adalah agar ia dapat bebas dekat dengan rakyatnya.

(3) Perjalanan hidup Ki Hajar Dewantara benar-benar ditandai dengan perjuangan dan pengabdian pada kepentingan bangsa dan negara.

(4) Ki Hajar Dewantara menamatkan Sekolah Dasar di ELS (Sekolah Dasar Belanda), kemudian melanjutkan pendidikannya ke STOVIA (Sekolah Dokter Bumiputera).

(5) Ia tidak dapat menamatkan pendidikan di sekolah tersebut karena sakit.

(6) Setelah itu, ia bekerja sebagai wartawan di beberapa surat kabar, seperti Sedyotomo, Midden Java, De Express, Oetoesan Hindia, Kaoem Moeda, Tjahaja Timoer, dan Poesara.

(7) Tulisan-tulisannya sangat komunikatif, tajam, dan patriotik sehingga mampu membangkitkan semangat antikolonial bagi pembacanya.

(8) Ki Hajar Dewantara juga aktif dalam organisasi sosial dan politik. Pada tahun 1908, ia aktif di seksi propaganda Boedi Oetomo untuk menyosialosasikan dan menggugah kesadaran masyarakat Indonesia.

(9) Ia selalu menyampaikan tentang pentingnya persatuan dan kesatuan dalam berbangsa dan bernegara.

(10) Akan tetapi, organisasi ini ditolak oleh pemerintahan Belanda karena dianggap dapat membangkitkan rasa nasionalisme rakyat dan menggerakkan kesatuan untuk menentang pemerintah kolonial Belanda.

(11) Komite Bumipoetra melancarkan kritik terhadap Pemerintah Belanda yang ingin merayakan seratus tahun kebebasan Belanda 
dari penjajahan Prancis dengan menarik uang dari rakyat jajahannya.

(12) Kemudian, ia dibuang ke Negara Belanda bersama kedua rekannya dan kembali ke tanah air pada tahun 1918 setelah memperoleh Europeesche Akte.

(13) Pada tanggal 3 Juli 1922 Ki Hajar Dewantara bersama dengan rekan-rekan seperjuangannya mendirikan perguruan yang bercorak nasional,

(14) Ki Hajar Dewantara pernah menjabat sebagai Menteri Pendidikan, pengajaran, dan Kebudayaan yang pertama.

(15) Ki Hajar Dewantara tidak hanya dianggap sebagai tokoh dan pahlawan pendidikan yang tanggal kelahirannya 2 Mei dijadikan hari Pendidikan Nasional, tetapi juga ditetapkan sebagai Pahlawan Pergerakan Nasional melalui surat keputusan Presiden RI No. 305 tahun 1959, tanggal 28 November 1959.

(16) Untuk melestarikan nilai dan semangat perjuangan Ki Hajar Dewantara penerus Taman Siswa mendirikan museum Dewantara Kirti Griya di Yogyakarta.

(17) Sebagai pahlawan yang dijuluki Bapak Pendidikan Indonesia, semangat dan jasa Ki Hajar Dewantara sepantasnya dikenang dan tidak dilupakan.

\section{b. Telaah Aspek Leksikal}

\section{1) Repetisi (Pengulangan)}

Repetisi adalah pengulangan satuan lingual (bunyi, suku kata, kata, atau bagian kalimat) yang dianggap penting untuk memberikan tekanan dalam sebuah konteks yang sesuai. Di dalam biografi ini terdapat dua repetisi, yaitu:

\section{a) Pengulangan kata sapaan}

(1) Nama kecil Ki Hajar Dewantara adalah Raden Mas Soewardi Soeryaningrat.

(2) Ketika berusia 40 tahun menurut hitungan Tahun Caka, Raden Mas Soewardi Soeryaningrat berganti nama menjadi Ki Hajar Dewantara.

(3) Perjalanan hidup Ki Hajar Dewantara benar-benar ditandai dengan perjuangan dan pengabdian pada kepentingan bangsa dan negara.

(4) Ki Hajar Dewantara menamatkan Sekolah Dasar di ELS (Sekolah Dasar Belanda), kemudian melanjutkan pendidikannya ke STOVIA (Sekolah Dokter Bumiputera). 
(5) Ki Hajar Dewantara juga aktif dalam organisasi sosial dan politik.

(6) Semangat Ki Hajar Dewantara terus menggebu.

(7) Ki Hajar Dewantara juga mengecam rencana perayaan itu melalui tulisannya yang berjudul "Als Ik Eens Nederlander was (Seandainya Aku Seorang Belanda) dan Een voor Allen maar Ook Allen voor Een (Satu untuk Semua, tetapi Semua untuk Satu juga)".

(8) Pada tanggal 3 Juli 1922 Ki Hajar Dewantara bersama dengan rekan-rekan seperjuangannya mendirikan perguruan yang bercorak nasional,

(9) Ki Hajar Dewantara berhasil meletakkan dasar-dasar pendidikan nasional bagi bangsa Indoneisa.

(10) Ki Hajar Dewantara pernah menjabat sebagai Menteri Pendidikan, pengajaran, dan Kebudayaan yang pertama.

(11) Ki Hajar Dewantara tidak hanya dianggap sebagai tokoh dan pahlawan pendidikan yang tanggal kelahirannya 2 Mei dijadikan hari Pendidikan Nasional,

(12) Ki Hajar Dewantara meninggal dunia pada tanggal 28 April 1959 di Yogyakarta.

(13) Untuk melestarikan nilai dan semangat perjuangan Ki Hajar Dewantara penerus Taman Siswa mendirikan museum Dewantara Kirti Griya di Yogyakarta.

(14) Sebagai pahlawan yang dijuluki Bapak Pendidikan Indonesia, semangat dan jasa Ki Hajar Dewantara sepantasnya dikenang dan tidak dilupakan.

\section{b) Pengulangan klausa}

(1) Ketika berusia 40 tahun menurut hitungan Tahun Caka, Raden Mas Soewardi Soeryaningrat berganti nama menjadi Ki Hajar Dewantara.

(2) Tujuannya berganti nama adalah agar ia dapat bebas dekat dengan rakyatnya.

\section{c) Pengulangan nomina}

(1) Ki Hajar Dewantara

(2) Belanda

(3) Pendidikan

(4) Yogyakarta

(5) Pahlawan

\section{2) Sinonim (Padan Kata)}

Sinonim adalah salah satu aspek leksikal untuk mendukung kepaduan wacana. Dalam biografi ini terdapat sinonim morfem (bebas) 
dengan morfem (terikat). Hal ini ditunjukkan pada data nomer (1) sampai (21).

(1) Sebagai pahlawan yang dijuluki Bapak Pendidikan Indonesia, semangat dan jasa Ki Hajar Dewantara sepantasnya dikenang dan tidak dilupakan.

\section{3) Kolokasi (Sanding Kata)}

Kolokasi adalah menggunakan pilihan kata yang cenderung digunakan secara berdampingan. Dalam biografi ini terdapat beberapa kolokasi atau sanding kata seperti pada kalimat berikut:

(1) Setelah itu, ia bekerja sebagai wartawan di beberapa surat kabar, seperti Sedyotomo, Midden Java, De Express, Oetoesan Hindia, Kaoem Moeda, Tjahaja Timoer, dan Poesara.

\section{SIMPULAN}

Berdasarkan hasil telaah peneliti, diperoleh hasil bahwa teks yang menjadi subjek kajian banyak memanfaatkan peranti wacana yang berupa aspek gramatikal dan aspek leksikal. Terdapat dua bagian dari aspek gramatikal yang sangat mendominasi teks wacana tersebut, yaitu pengacuan (referensi) dan konjungsi. Secara leksikal, penelitian ini menemukan beberapa peranti wacana yang termasuk dalam aspek leksikal antara lain repetisi, sinonim, antonim, kolokasi. Dari ke empat aspek ini yang paling mendominasi kemunculannya adalah repetisi. Terdapat dua jenis repetisi yang paling dominan, yaitu repetisi epizeuksis dan repetisi anafora. Setelah dua jenis repetisi tersebut, repetisi yang sering muncul adalah jenis repetisi nomina. Sedangkan repetisi yang tidak ditemukan pada teks yang ditelaah adalah jenis repetisi tautotes, repetisi epistrofa, repetisi mesodiplosis, repetisi simplok dan repetisi utuh. Selain repetisi, kemunculan aspek leksikal yang kedua adalah kolokasi. Antonim dan sinonim menempati peringkat ketiga frekuensi kemunculannya setelah kolokasi. Masing-masing peranti kohesi wacana ini membentuk satu kesatuan wacana yang utuh dan koheren.

\section{DAFTAR PUSTAKA}

Andriyani, Feni. 2013. Analisis Tekstual dan Kontekstual dalam Novel Traju Mas Karya Imam Sardjono. Universitas Muhammadiyah Purworejo. Vol. 03. Hal: 12-18.

Djajasudarma, Fatimah. 1994. Wacana: Pemahaman dan Hubungan Antarunsur. Bandung: PT Eresco.

Eriyanto. 2001. Analisis Wacana, Pengantar Analisis Isi Media. Yogyakarta: LKIS. Halliday, M.A.K., \& Ruqaiya Hasan. 1976. Cohesion in English. London: Longman. 
Kosasih. 2011. Ketatabahasaan dan Kesusastraan. Bandung: Yrama Widya.

Mulyana. 2005. Kajian Wacana: Teori, Metode dan Aplikasi Prinsip-prinsip Analisis Wacana. Yogyakarta: Tiara Wacana.

Sobur, Alex. 2001. Analisis Teks Media : Suatu Pengantar Untuk Analisis Wacana, Analisis Semiotik, Dan Analisis Framing, Bandung : PT. Remaja Rosda Karya.

Sumarlam dkk. 2003. Analisis Wacana Tekstual dan Kontekstual. Surakarta: Universitas Sebelas Maret.

Tarigan, H.G. 1993. Strategi Pengajaran dan Pembelajaran Bahasa. Bandung: Angkasa.

Wijana, I Dewa Putu dan Rohmadi, Muhammad. 2011. Analisis Wacana Pragmatik: Kajian Teori dan Analisis. Surakarta: Yuma Pustaka. 